\title{
The Potential of Cerebrolysin in the Treatment of Schizophrenia
}

\author{
Gonzalo Flores ${ }^{1 *}$, Marco Atzori ${ }^{2,3}$ \\ ${ }^{1}$ Laboratorio de Neuropsiquiatría, Instituto de Fisiología, Universidad Autónoma de Puebla, Puebla, México \\ ${ }^{2}$ Facultad de Ciencias, Universidad Autónoma de San Luis Potosí, San Luis Potosí, Mexico \\ ${ }^{3}$ School of Behavior and Brain Sciences, University of Texas at Dallas, Richardson, USA \\ Email: "gonzaloflores56@gmail.com, ${ }^{*}$ gonzalo.flores@correo.buap.mx
}

Received 16 April 2014; revised 26 May 2014; accepted 12 June 2014

Copyright (C) 2014 by authors and Scientific Research Publishing Inc.

This work is licensed under the Creative Commons Attribution International License (CC BY). http://creativecommons.org/licenses/by/4.0/

(c) (†) Open Access

\section{Abstract}

Schizophrenia and psychosis are psychiatric condition whose neural mechanisms are yet incompletely known, and for which pharmacological treatment is too often ineffective in a growing clinical cohort. Recently, dendritic morphological changes in arborization and dendritic spine density in limbic regions has been reported in postmortem tissue from schizophrenic patients and in animal models of schizophrenia, suggesting that the use of medication improving synaptogenesis may be beneficial as additional treatment of psychotic patients. Cerebrolysin $(\mathrm{Cbl})$ is a drug available for clinical with active neuropeptides fragments that mimics the action of endogenous neurotrophic factors such as BDNF, GDNF, CNTF and NGF, which improves the integrity of the neuronal circuits as well as cognitive and behavioral performance by exerting a neuroprotective effect and promoting the generation of new functional synapses. Recent work from our laboratory has shown that $\mathrm{Cbl}$ ameliorates synaptic and dendritic pathology in animal models of schizophrenia by increasing synaptic density and restoring neuronal cytoarchitecture. This neuroprotective effect improves the integrity of the neuronal circuits and improves cognitive and behavioral performance. Importantly, Cbl treatment seems to be safe when used in combination with neuroleptics such as risperidone. The present article analyzes the potential of $\mathrm{Cbl}$ in the treatment of neurodevelopmental disease, and reviews the current literature on the effects of $\mathrm{Cbl}$ in in vivo animal models of neurodevelopmental disorders like schizophrenia.

\section{Keywords}

Cerebrolysin, Neurotrophic Factors, Schizophrenia, Prefrontal Cortex, Hippocampus, Amygdala

*Corresponding author. 


\section{Introduction}

Schizophrenia is a complex disorder of thought, perception and social interactions affecting $1 \%$ of the world population. This severe mental disorder starts at early adulthood during the synaptic pruning and myelination process [1] with an individual combination of positive, negative, and affective symptoms as well as cognitive deficits, while the severity of these symptoms can change over time depending on the disease stage [1]. Various theories have been advanced to explain schizophrenia; amongst them, the altered communication between temporal-prefrontal circuits theory postulates an altered synaptic communications between temporal regions as hippocampus and basolateral amygdala (BLA) with the prefrontal cortex (PFC) in mediating some of the behavioral manifestations of this disorder. In recent years, clinical imaging and pathological studies have provided strong evidence for structural and molecular changes in the PFC, BLA and hippocampal formation (HF) of schizophrenic brains that are suggestive of abnormalities in brain development and plasticity. It has been suggested that neuropathologies associated with schizophrenia may result from developmental abnormalities in BLA, hippocampus and/or PFC efferents that alter normal maturation and functionality of limbic system. In addition, postmortem studies of schizophrenic patients have demonstrated a significant reduction in the dendritic arbor and dendritic spine density [2] [3], whereas, molecular studies have demonstrated that neurotrophins such as brainderived neurotrophic factor (BDNF) are altered in cortical regions of schizophrenic patients [4]. Moreover, a recent report [5] has shown that serum levels of another neurotrophic factor, neural grow factor (NGF), are altered in the schizophrenic patients [5]. Interestingly, animal studies clearly indicate a role of hippocampal, BLA and PFC inputs in modulating nucleus accumbens (NAcc) and mesolimbic dopaminergic activity. For example, recent studies with neonatal lesions of the ventral hippocampus in rats have revealed a postpubertal emergence of heightened sensitivity of the mesolimbic dopaminergic system. In addition, these animals have also shown changes in dendritic arborization and dendritic spine density at the level of the prefrontal cortex and nucleus [6]-[11]. Furthermore, bilateral neonatal ventral hippocampal lesion (NVHL) also caused a reduction in BDNF levels in the PFC at postpubertal age [12]. These findings suggest that schizophrenia is a disorder of brain connectivity with reduced synaptic communication at level of the PFC, BLA and hippocampus.

Cerebrolysin (Cbl) improves the integrity of the neuronal circuits as well as cognitive and behavioral performance [10] [11] [13]-[15] by exerting a neuroprotective effect and promoting the generation of new functional synapses. These findings induced us to decide to analyze the potential of $\mathrm{Cbl}$ in the treatment of neurodevelopmental disease, such as schizophrenia, and review the current literature on its possible mechanisms of action in studies using in vivo animal models of neurodevelopmental disorders such as schizophrenia.

\section{Prefrontal Cortex Neuropathology in Schizophrenia}

The PFC participates in the regulation of attention, inhibition, cognitive control, motivation, and emotion through connections with posterior cortical and subcortical structures such as the hippocampus, the amygdala, and the nucleus accumbens (for review sees Arnsten et al. [16]). Interestingly, patients with schizophrenia exhibit profound deficits in PFC functions that are a fundamental component of this illness (for review see Arnsten et al. [16]. Multiple lines of evidence suggest that the PFC is a primary site of dysfunction in schizophrenia [16]. For example, Glantz and Lewis [17] demonstrated reduced levels of synaptophysin (SYP) inmunoreactivity in the PFC of schizophrenic patients. SYP protein has been shown to be critical for regulating neurotransmitter release and synaptic plasticity, a process thought to be disrupted in schizophrenia. However, recent reports of postmortem brain studies from schizophrenic patients have shown that not only the PFC, but also other brain regions such as the medial temporal cortex, the visual association cortex, the hippocampus, and the thalamus also exhibit a decreased expression in the levels of [17]-[32], suggestive of gross synaptic alterations in the brain of schizophrenic patients.

Consistent with these findings, schizophrenia has been postulated to derive from a neurodevelopmental aberration that interferes with cortical neuronal maturation and abnormal network architecture at adolescence [33]. Interestingly, in animal models, chronic stress such as social isolation or movement restriction may alter the synaptic connectivity at the level of PFC and hippocampus [7] [34]-[37]. For all these reasons, exposure to stress may be a key factor in the precipitation of schizophrenic psychosis in adolescence and in the subsequent exacerbation of its symptoms [38]-[41], suggesting that the environment can and does interact with an already vulnerable circuitry to aggravate cortical deterioration.

The findings of abnormal placement of pre-alpha cell clusters, heterotopic displacement of neurons, and ab- 
normal orientation of pyramidal cells in the entorhinal cortex and hippocampus of post-mortem schizophrenic brain are indicative of developmental aberrations in neuronal migration [42]-[45].

It is interesting to note that decreases in PFC and hippocampal immunoreactivity to markers for GABaergic interneurons-particularly the calcium binding protein parvalbumin but also the modulatory peptide, somatostatin [46]-[50] are one of the most consistent findings in post-mortem schizophrenic brains. A growing number of reports suggest that PFC GABAergic interneurons are critical in the development of the normal puberty [51]-[53].

It is known that brain axonal tracts are myelinated progressively across the lifespan in a region- and function-specific manner. Interestingly, post-mortem brain studies from patients with schizophrenia have implicated a myelin dysfunction in this disorder. In this framework, it is tempting to speculate that PFC myelination deficits [54] [55] and structural abnormalities in white matter detected in post-mortem brains from schizophrenic patients [56] may be caused by a developmental alteration of the myelination process that occurs within the brain in a region- and function-specific fashion during a lifespan. These observations together with a reduction in mRNA [55] and protein levels [45] [57] of myelin basic protein (MBP) in schizophrenia, supports the brain communication disorder hypothesis with emphasis in PFC functions.

The laminar distribution of NADPH-diaphorase-positive neurons, in the temporal and frontal cortices, suggests unusual neuronal migration [58]. Interestingly, since the finding by Weinberger et al. [59] that lateral ventricular size in schizophrenic patients is bigger than control, more than 300 peer-reviewed articles have delineated the subtle neuroanatomic abnormalities in this mental illness (for review sees Glahn et al. [60]. Considerable evidence from neuroimaging and epidemiological studies has now accumulated in support of a neurodevelopmental hypothesis of schizophrenia. Magnetic Resonance Image (MRI) studies have detected cortical volume reduction over time in patients with schizophrenia [61]. Furthermore, neural densities in the schizophrenic frontal cortex and hippocampus are reported to be decreased without concomitant gliosis [62] [63], although evidence to the contrary has also been reported [64].

Despite an impressive array of evidence implicating abnormal neurodevelopment in schizophrenia, few studies have provided conclusive evidence with respect to the biochemical substrates of such abnormalities. However, reports of a reduced expression of synapsin, microtubule associated proteins MAP2, DARPP-32, the dendritic protein neurogranin, and synaptophysin in the PFC of post-mortem schizophrenic brains provide molecular indication of disturbed synapse development and plasticity [65] [66].

\section{Hippocampus and Amygdala in Schizophrenia}

Similar to PFC, hippocampal and amygdala abnormalities have been reported in schizophrenia [67]-[72]. Structural and functional neuroimaging studies now provide strong evidence that hippocampal and amygdala volume are reduced in schizophrenia [73]-[79]. In addition, the extent of the volume loss has been correlated with positive, negative, and cognitive symptoms [80] [81]. Consistent with this idea such synaptic alterations in schizophrenia may—at least in part—be a cause for brain impaired (long-range) connectivity in this disorder. Specifically, post-mortem studies of schizophrenic patients show a reduced dendritic spine density in the subiculum andin the CA3 area [82] [83], as well as reduced spine size on CA3 pyramidal neurons [83]. Moreover, a lower number of synaptic contacts formed by individual mossy fibers tracts on CA3 pyramidal neurons have been reported in schizophrenia [84]. Interestingly, several reports show that cerebral blood flow of the schizophrenic patients is higher at hippocampus level [85] [86]. Furthermore, Schobel et al. [87] have shown that hippocampal basal blood flow volume correlates with both positive and negative symptoms in the schizophrenia.

In addition, in the post-mortem schizophrenic hippocampus and PFC the polysialylated form of the neural cell adhesion molecule (PSA-NCAM) — which is expressed specifically in PFC and hippocampal interneurons [88] is altered [89]-[91]. Interestingly, several reports show a dysfunction of GABAergic inhibition and a consequent imbalance between excitation and inhibition in the cerebral cortex in schizophrenia animal models [92]-[96]. In addition, various isoforms of NCAM, expressed in a developmentally regulated manner, play a crucial role in the migration of neural cells as well as in the guidance of growing axons, and, in the adult brain, are implicated in maintaining synaptic plasticity in structures such as the hippocampus, where a persistent expression of the embryonic form of the molecule is observed [90].

Consistent with these findings the cell pattern and orientation of cells in the hippocampus [97], and the dendritic arborization and density of dendritic spines in subicular pyramidal neurons from post-mortem schizoph- 
renic patients are disrupted [98]. All these data are indicative of a dysfunctional hippocampal and amygdala circuitry in schizophrenia.

\section{Neurotrophic-Like Factor Such as Cerebrolysin in Neuropsychiatric Disorders}

Cerebrolysin (Cbl) is the only drug available for clinical use containing active fragments of important neurotrophic factors [99]. The active fragments are small neuropeptides which cross the blood-brain barrier (BBB) and mimic the action of endogenous neurotrophic factors such as BDNF, GDNF, CNTF and NGF and others [100] [101]. The neurotrophic action of the Cbl helps in the survival of neurons and prevents the cell death [102]. In addition, several reports suggest that $\mathrm{Cbl}$ induces neuroprotection when there is a damage of the brain and also induce neurogenesis. These two actions (neuroprotection and neurogenesis) maintain [99] [102]. These may be some of the reasons why $\mathrm{Cbl}$ is effective in the treatment of neurodegenerative diseases like multiple sclerosis, Parkinson's disease, Alzheimer's disease, dementia, and acute or chronic stroke [99]. In addition, recent reports suggest that $\mathrm{Cbl}$ increases synaptic communication by increasing dendritic arborization as well as the number of dendritic spines in cortical regions such as PFC and hippocampus [10] [11] [13] [14]. Moreover, Cbl is also effective in the treatment of neurodevelopmental disorder such as autism and schizophrenia [103]-[106].

\section{Neonatal Ventral Hippocampus Lesion and Cerebrolysin}

Rats with bilateral excitotoxic neonatal ventral hippocampal lesion (nVHL) have been widely accepted as a neurodevelopmental model of schizophrenia-related behaviors [107]-[110]. These rats exhibit behavioral and neurochemical changes that manifest mainly after puberty [109]-[111]. Behavioral and neurochemical changes include locomotor hyperresponsiveness to stress [7] [107] [108] [112], deficits in social interaction [113] [114], sensorimotor gating [115] [116], spatial learning and working memory problems [112] [117], decreased attention [116], low levels of brain-derived neurotrophic factor (BDNF) [118] [119] and nerve growth factor-inducible B (NGFB) [120]. Together with the behavioral and neurochemical alterations, neural morphological changes have been reported in this model [6] [7] [9]-[11]. Post-pubertally, nVHLs induce atrophy of pyramidal neurons of the prefrontal cortex (PFC), basolateral amygdala (BLA), and medium spiny neurons of the nucleus accumbens (Nacc) [6] [7] [9] [10]. Our recent report suggests that Cbl promotes recovery of dendritic and neuronal damage of the pyramidal neurons of the PFC and medium spiny neurons of the Nacc in post-pubertal nVHL rats [10]. In addition, behavioral changes such as locomotor hyperresponsiveness to stress and deficits in social interaction and sensorimotor gating were in part also recovered by Cbl treatment in nVH-lesion animals [10]. As we mention before, several reports have suggested that the BLA is dysfunctional in schizophrenic patients [121] and our group recently reported that nVHL animals show dendritic atrophy and reduced spinogenesis in the BLA at adult age [9] [10]. However, Cbl does not produce any amelioration after dendritic alterations of the BLA pyramidal neurons following $\mathrm{nVHL}$ in rats [11]. Another finding in the nVHL schizophrenia model is the reduction in the number of neurons in the PFC and BLA, measured by stereological analysis [10] [11]. Interestingly, Cbl treatment ameliorates the cells loss observed in the PFC and BLA of the post-puberal nVHL animals [10] [11]. All these data suggest that Cbl has a potential use in the treatment of schizophrenia.

\section{Neurotropic-Like Factor in Schizophrenia}

Neurotrophins are a large family of dimeric polypeptides that promote the growth and the differentiation of developing neurons in the central and peripheral nervous systems as well as the survival of neuronal cells in response to stress. The fact that schizophrenia is a neurodevelopmental disorder with reduced connectivity amount limbic regions induced by synaptic alterations [68] explains the growing interest in the role of neurotrophins in the pathophysiology of schizophrenia. Several recent reports have shown a reduced plasma and serum level of neural grow factor (NGF) and brain-derived neurotrophic factor (BDNF) levels in drug-naïve as well as medicated schizophrenic patients compared to healthy controls. In addition low serum BDNF levels were associated with reduction in hippocampal volume at the onset of schizophrenia [122]. Furthermore, a recent report has shown significantly higher levels of methylation of BDNF promoter in patients with schizophrenia compared to controls [123]. Consistently with these findings, risperidone-atypical antipsychotic drugs-elevates BDNFbut not NGF-levels in schizophrenic patients [124]. All these data support the hypothesis that schizophrenia is a neurodevelopmental disorder with impaired synaptic communication between the hippocampus and the amyg- 
dala on one hand, and the PFC on the other hand. Accordingly, drugs with neurotrophic-like effects that increase BDNF and NGF levels result in better synaptic communication with beneficial effects in schizophrenia.

Cbl has recently been used in the therapy of the schizophrenic symptoms [106], where it was found to improve cognitive and memory functions in patients dominated by negative symptoms. Interestingly, a recent report suggests that low BDNF is associated with cognitive impairment in chronic patients with schizophrenia [125]. In addition, a growing body of evidence shows that oxidative stress damage may relate to the range of cognitive deficits associated with schizophrenia [126]. Interestingly, oxidative stress is the condition arising from imbalance between toxic oxygen species and antioxidant system. Brain tissue is highly vulnerable to oxidative stress damage due to relatively low levels of endogenous antioxidants, high metal content and levels of polyunsaturated fatty acids, with elevated oxygen [127]-[129]. In addition, protective mechanism includes various antioxidant enzymes such as superoxide dismutase (SOD) and gluthatione peroxidase (GPX) [126] [130]. In the schizophrenic brains, a dysfunction in the protective mechanisms of oxidative stress has been suggested [126] [130]. An increase in oxidative stress together with a decline in membrane essential polyunsaturated fatty acids leads to enhanced lipid peroxidation [131]. In addition, antioxidant enzymes such as superoxide dismutase (SOD), glutathion peroxidase (GpX) and catalase (CAT) are often measured for quantifying antioxidant defense in schizophrenia [132] with conflicting results. Some studies report increased antioxidant defense in schizophrenia, whereas others report opposite conclusion [126] [130]. We measured the two biomarkers of oxidative stress, serum superoxide dismutase (SOD) activity and concentration of nitrites as indicator of the nitric oxide (NO) levels in the psychotic schizophrenic patients before and after 4 weeks with Cbl (10 mL/day) on top of the standard haloperidol treatment. Interestingly, the NO levels and SOD activity were reduced in the schizophrenic patients with Cbl treatment (data unpublished). In agreement with our results, another report suggests that Cbl induces a decrease on the CAT and SOD levels [133].

\section{Activity of Cerebrolysin on Neuroimmune Antigens}

A new hypothesis associates neurodevelopmental conditions including schizophrenia but also autism spectrum disorder (ASD) with alterations of the immune system response, either during fetal development [134] or as sensitization of the response to stressors during adulthood [135]-[137]. These considerations suggest the possibility that among the actions of the peptidic mixture making up $\mathrm{Cbl}$ is the decrease of a neuroinflammation associated with neuropsychiatric disease. While-at the current state-this possibility is only theoretical, it is worth to consider the potential of this avenue of research. Among the few exploratory studies on the effects of $\mathrm{Cbl}$ on the innate or adaptive immune system are an early report that in vitro treatment of mouse bone marrow with Cbl stimulated the response to Thy-1 (or CD90) [138], which is a marker for neuronal axons, and a second clinical study on children, which showed that 1-month intramuscular treatment with Cbl results in increased activation of CD19+ cells, with "simultaneous normalization of IgA and IgG" immunoglobulins and normalization of the otherwise altered levels of CD25+ and HLA DR in lymphocytes, achieving the parameters of the control group, together with activation of T-cells [139]. The same results were repeated and widened in a later study on a cohort of ADHD children affected by recurrent acute viral respiratory infections with parallel alterations in systemic blood immune parameters [139]. A more recent study identified cytoprotective properties of Cbl towards both $\mathrm{B}$ and $\mathrm{T}$ lymphocytes, favoring the survival of immunocompetent cells, and possibly stimulating the formation of immune memory B cells [140]. While it is premature to even formulate a hypothesis on whether any avenue of action of Cbl occurs through an interaction with the immune system, the efficacy of this peptide mixture in the treatment of conditions with an obvious immune component is worth being further investigated.

\section{Conclusion}

A growing body of evidence shows that schizophrenia is a disorder of brain connectivity with reduced synaptic communication at level of the PFC, BLA and hippocampus. This disconnection is expressed at puberty when exposure to stress, which may be a key factor in the precipitation of schizophrenic psychosis in adolescence together with the subsequent exacerbation of its symptoms [38]-[41]. Therefore, the interaction between stresses with a vulnerable limbic circuitry exacerbates cortical dysfunction. Consistent with these data, neurotrophins, a family of polypeptides or small proteins that exert robust effects on neuronal survival, synapse stabilization, and synaptic function [141], may play a critical role in this interaction. These considerations suggest the possibility that $\mathrm{Cbl}$ a drug available for clinical with active neuropeptides fragments that mimics the action of endogenous 
neurotrophic factors such as BDNF, GDNF, CNTF and NGF and others [100] [101], may help in the treatment of the schizophrenia.

\section{Acknowledgements}

GF and MA acknowledge the National Research System of Mexico for membership.

\section{Conflict of Interest}

All authors have no conflicts of interest.

\section{Funding Sources}

Funding for this study was provided by grants from VIEP-BUAP grant (No. FLAG-SAL14-Ind), PROMEP (CA-BUAP-120) and CONACYT grant (No. 129303 and No. 138663) to G. Flores. None of the funding institution had any further role in the study design, the collection of data, analyses and interpretation of data, writing of the report or in the decision to submit the paper for publication and interpretation of data, writing of the report or the decision to submit the paper for publication.

\section{References}

[1] Schmitt, A., Malchow, B., Hasan, A. and Falkai, P. (2014) The Impact of Environmental Factors in Severe Psychiatric Disorders. Frontiers in Neuroscience, 8, 1-10.

[2] Kalus, P., Müller, T.J., Zuschratter, W. and Senitz, D. (2000) The Dendritic Architecture of Prefrontal Pyramidal Neurons in Schizophrenic Patients. NeuroReport, 11, 3621-3625. http://dx.doi.org/10.1097/00001756-200011090-00044

[3] Glantz, L.A. and Lewis, D.A. (2000) Decreased Dendritic Spine Density on Prefrontal Cortical Pyramidal Neurons in Schizophrenia. Archives of General Psychiatry, 57, 65-73.

[4] Nieto, R., Kukuljan, M. and Silva, H. (2013) BDNF and Schizophrenia: From Neurodevelopment to Neuronal Plasticity, Learning, and Memory. Frontiers in Psychiatry, 4, 1-11.

[5] Ajami, A., Hosseini, S.H., Taghipour, M. and Khalilian, A. (2014) Changes in Serum Levels of Brain Derived Neurotrophic Factor and Nerve Growth Factor-Beta in Schizophrenic Patients before and after Treatment. Scandinavian Journal of Immunology. http://dx.doi.org/10.1111/sji.12158

[6] Flores, G., Alquicer, G., Silva-Gomez, A.B., Zaldivar, G., Stewart, J., Quirion, R. and Srivastava, L.K. (2005) Alterations in Dendritic Morphology of Prefrontal Cortical and Nucleus Accumbens Neurons in Post-Pubertal Rats after Neonatal Excitotoxic Lesions of the Ventral Hippocampus. Neuroscience, 133, 463-470. http://dx.doi.org/10.1016/j.neuroscience.2005.02.021

[7] Alquicer, G., Morales-Medina, J.C., Quirion, R. and Flores, G. (2008) Postweaning Social Isolation Enhances Morphological Changes in the Neonatal Ventral Hippocampal Lesion Rat Model of Psychosis. Journal of Chemical Neuroanatomy, 35, 179-187. http://dx.doi.org/10.1016/j.jchemneu.2007.10.001

[8] Solis, O., Vázquez-Roque, R.A., Camacho-Abrego, I., Gamboa, C., De La Cruz, F., Zamudio, S. and Flores, G. (2009) Decreased Dendritic Spine Density of Neurons of the Prefrontal Cortex and Nucleus Accumbens and Enhanced Amphetamine Sensitivity in Postpubertal Rats after a Neonatal Amygdala Lesion. Synapse, 63, 1143-1153. http://dx.doi.org/10.1002/syn.20697

[9] Bringas, M.E., Morales-Medina, J.C., Flores-Vivaldo, Y., Negrete-Diaz, J.V., Aguilar-Alonso, P., León-Chávez, B.A., Lazcano-Ortiz, Z., Monroy, E., Rodríguez-Moreno, A., Quirion, R. and Flores, G. (2012) Clozapine Administration Reverses Behavioral, Neuronal, and Nitric Oxide Disturbances in the Neonatal Ventral Hippocampus Rat. Neuropharmacology, 62, 1848-1857. http://dx.doi.org/10.1016/j.neuropharm.2011.12.008

[10] Vázquez-Roque, R.A., Ramos, B., Tecuatl, C., Juárez, I., Adame, A., de la Cruz, F., Zamudio, S., Mena, R., Rockenstein, E., Masliah, E. and Flores, G. (2012) Chronic Administration of the Neurotrophic Agent (Cerebrolysin) Ameliorated the Behavioral and Morphological Changes Induced by Neonatal Ventral Hippocampus Lesion in the Rat. Journal Neuroscience Research, 90, 288-306. http://dx.doi.org/10.1002/jnr.22753

[11] Vázquez-Roque, R.A., Ubhi, K., Masliah, E. and Flores, G. (2014) Chronic Cerebrolysin Administration Attenuates Neuronal Abnormalities in the Basolateral Amygdala Induced by Neonatal Ventral Hippocampus Lesion in the Rat. Synapse, 68, 31-38. http://dx.doi.org/10.1002/syn.21718

[12] Weickert, C.S., Hyde, T.M., Lipska, B.K., Herman, M.M., Weinberger, D.R. and Kleinman, J.E. (2003) Reduced Brain-Derived Neurotrophic Factor in Prefrontal Cortex of Patients with Schizophrenia. Molecular Psychiatry, 8, 
592-610. http://dx.doi.org/10.1038/sj.mp.4001308

[13] Juárez, I., González, D.J., Mena, R. and Flores, G. (2011) The Chronic Administration of Cerebrolysin Induces Plastic Changes in the Prefrontal Cortex and Dentate Gyrus in Aged Mice. Synapse, 65, 1128-1135. http://dx.doi.org/10.1002/syn.20950

[14] Alcántara-González, F., Gamboa, C., de la Cruz, F., Zamudio, S. and Flores, G. (2012) Combined Administration of Cerebrolyisin and Donepezil Induces Plastic Changes in Medial Prefrontal Cortex and Dentate Gyrus in Aged Mice. Synapse, 66, 938-949. http://dx.doi.org/10.1002/syn.21588

[15] Flores, G., Hernández-Cabrera, J., Santamaria-Juárez, C., Vázquez-Roque, R.A., Monserrat-Hernández, E., GómezVillalobos, M.J., Flores-Hernández, J., Atonal-Flores, F. and López-López, J.G. (2014) Chronic Administration of the Resveratrol or N-PEP-12 Ameliorates the Endothelial Dysfunction in Aging Rats. Pharmacology \& Pharmacy, 5, 69-74. http://dx.doi.org/10.4236/pp.2014.51011

[16] Arnsten, A.F., Wang, M.J. and Paspalas, C.D. (2012) Neuromodulation of Thought: Flexibilities and Vulnerabilities in Prefrontal Cortical Network Synapses. Neuron, 76, 223-239. http://dx.doi.org/10.1016/j.neuron.2012.08.038

[17] Eastwood, S.L. and Harrison, P.J. (1995) Decreased Synaptophysin in the Medial Temporal Lobe in Schizophrenia Demonstrated Using Immunoautoradiography. Neuroscience, 69, 339-343. http://dx.doi.org/10.1016/0306-4522(95)00324-C

[18] Eastwood, S.L., Burnet, P.W. and Harrison, P.J. (1995) Altered Synaptophysin Expression as a Marker of Synaptic Pathology in Schizophrenia. Neuroscience, 66, 309-319. http://dx.doi.org/10.1016/0306-4522(94)00586-T

[19] Perrone-Bizzozero, N.I., Sower, A.C., Bird, E.D., Benowitz, L.I., Ivins, K.J. and Neve, R.L. (1996) Levels of the Growth-Associated Protein GAP-43 Are Selectively Increased in Association Cortices in Schizophrenia. Proceedings of the National Academy of Sciences of the United States of America, 93, 14182-14187. http://dx.doi.org/10.1073/pnas.93.24.14182

[20] Glantz, L.A. and Lewis, D.A. (1997) Reduction of Synaptophysin Immunoreactivity in the Prefrontal Cortex of Subjects with Schizophrenia. Regional and Diagnostic Specificity. JAMA Psychiatry, 54, 943-952. http://dx.doi.org/10.1001/archpsyc.1997.01830220065010

[21] Davidsson, P., Gottfries, J., Bogdanovic, N., Ekman, R., Karlsson, I., Gottfries, C.G. and Blennow, K. (1999) The Synaptic-Vesicle-Specific Proteins rab3a and Synaptophysin Are Reduced in Thalamus and Related Cortical Brain Regions in Schizophrenic Brains. Schizophrenia Research, 40, 23-29. http://dx.doi.org/10.1016/S0920-9964(99)00037-7

[22] Eastwood, S.L. and Harrison, P.J. (1999) Detection and Quantification of Hippocampal Synaptophysin Messenger RNA in Schizophrenia Using Autoclaved, Formalin-Fixed, Paraffin Wax-Embedded Sections. Neuroscience, 93, 99106. http://dx.doi.org/10.1016/S0306-4522(99)00096-2

[23] Karson, C.N., Mrak, R.E., Schluterman, K.O., Sturner, W.Q., Sheng, J.G. and Griffin, W.S. (1999) Alterations in Synaptic Proteins and Their Encoding mRNAs in Prefrontal Cortex in Schizophrenia: A Possible Neurochemical Basis for “Hypofrontality”. Molecular Psychiatry, 4, 39-45. http://dx.doi.org/10.1038/sj.mp.4000459

[24] Landén, M., Davidsson, P., Gottfries, C.G., Grenfeldt, B., Stridsberg, M. and Blennow, K. (1999) Reduction of the Small Synaptic Vesicle Protein Synaptophysin but Not the Large Dense Core Chromogranins in the Left Thalamus of Subjects with Schizophrenia. Biological Psychiatry, 46, 1698-1702. http://dx.doi.org/10.1016/S0006-3223(99)00160-2

[25] Vawter, M.P., Howard, A.L., Hyde, T.M., Kleinman, J.E. and Freed, W.J. (1999) Alterations of Hippocampal Secreted N-CAM in Bipolar Disorder and Synaptophysin in Schizophrenia. Molecular Psychiatry, 4, 467-475. http://dx.doi.org/10.1038/sj.mp.4000547

[26] Eastwood, S.L. and Harrison, P.J. (2001) Synaptic Pathology in the Anterior Cingulate Cortex in Schizophrenia and Mood Disorders. A Review and a Western Blot Study of Synaptophysin, GAP-43 and the Complexins. Brain Research Bulletin, 55, 569-578. http://dx.doi.org/10.1016/S0361-9230(01)00530-5

[27] Eastwood, S.L., Cotter, D. and Harrison, P.J. (2001) Cerebellar Synaptic Protein Expression in Schizophrenia. Neuroscience, 105, 219-229. http://dx.doi.org/10.1016/S0306-4522(01)00141-5

[28] Webster, M.J., Shannon Weickert, C., Herman, M.M., Hyde, T.M. and Kleinman, J.E. (2001) Synaptophysin and GAP-43 mRNA Levels in the Hippocampus of Subjects with Schizophrenia. Schizophrenia Research, 49, 89-98. http://dx.doi.org/10.1016/S0920-9964(00)00052-9

[29] Hemby, S.E., Ginsberg, S.D., Brunk, B., Arnold, S.E., Trojanowski, J.Q. and Eberwine, J.H. (2002) Gene Expression Profile for Schizophrenia: Discrete Neuron Transcription Patterns in the Entorhinal Cortex. JAMA Psychiatry, 59, 631640. http://dx.doi.org/10.1001/archpsyc.59.7.631

[30] Mukaetova-Ladinska, E., Hurt, J., Honer, W.G., Harrington, C.R. and Wischik, C.M. (2002) Loss of Synaptic but Not Cytoskeletal Proteins in the Cerebellum of Chronic Schizophrenics. Neuroscience Letters, 317, 161-165. 
http://dx.doi.org/10.1016/S0304-3940(01)02458-2

[31] Halim, N.D., Weickert, C.S., McClintock, B.W., Hyde, T.M., Weinberger, D.R., Kleinman, J.E. and Lipska, B.K. (2003) Presynaptic Proteins in the Prefrontal Cortex of Patients with Schizophrenia and Rats with Abnormal Prefrontal Development. Molecular Psychiatry, 8, 797-810. http://dx.doi.org/10.1038/sj.mp.4001319

[32] Chambers, J.S., Thomas, D., Saland, L., Neve, R.L. and Perrone-Bizzozero, N.I. (2005) Growth-Associated Protein 43 (GAP-43) and Synaptophysin Alterations in the Dentate Gyrus of Patients with Schizophrenia. Progress in NeuroPsychopharmacology \& Biological Psychiatry, 29, 283-290.

[33] Collin, G., Kahn, R.S., de Reus, M.A., Cahn, W. and van den Heuvel, M.P. (2014) Impaired Rich Club Connectivity in Unaffected Siblings of Schizophrenia Patients. Schizophrenia Bulletin, 40, 438-448. http://dx.doi.org/10.1093/schbul/sbt162

[34] Silva-Gómez, A.B., Rojas, D., Juárez, I. and Flores, G. (2003) Decreased Dendritic Spine Density on Prefrontal Cortical and Hippocampal Pyramidal Neurons in Postweaning Social Isolation Rats. Brain Research, 983, 128-136. http://dx.doi.org/10.1016/S0006-8993(03)03042-7

[35] Sala-Catala, J., Torrero, C., Regalado, M., Salas, M. and Ruiz-Marcos, A. (2005) Movements Restriction and Alterations of the Number of Spines Distributed Along the Apical Shafts of Layer V Pyramids in Motor and Primary Sensory Cortices of the Peripubertal and Adult Rat. Neuroscience, 133, 137-145. http://dx.doi.org/10.1016/j.neuroscience.2005.01.009

[36] Ferdman, N., Murmu, R.P., Bock, J., Braun, K. and Leshem, M. (2007) Weaning Age, Social Isolation, and Gender, Interact to Determine Adult Explorative and Social Behavior, and Dendritic and Spine Morphology in Prefrontal Cortex of Rats. Behavioural Brain Research, 180, 174-182. http://dx.doi.org/10.1016/j.bbr.2007.03.011

[37] Wang, Y.C., Ho, U.C., Ko, M.C., Liao, C.C. and Lee, L.J. (2012) Differential Neuronal Changes in Medial Prefrontal Cortex, Basolateral Amygdala and Nucleus Accumbens after Postweaning Social Isolation. Brain Structure and Function, 217, 337-351. http://dx.doi.org/10.1007/s00429-011-0355-4

[38] Breier, A., Schreiber, J.L., Dyer, J. and Pickar, D. (1991) National Institute of Mental Health Longitudinal Study of Chronic Schizophrenia. Prognosis and Predictors of Outcome. JAMA Psychiatry, 48, 239-246.

[39] Nuechterlein, K.H., Dawson, M.E., Gitlin, M., Ventura, J., Goldstein, M.J., Snyder, K.S., Yee, C.M. and Mintz, J. (1992) Developmental Processes in Schizophrenic Disorders: Longitudinal Studies of Vulnerability and Stress. Schizophrenia Bulletin, 18, 387-425. http://dx.doi.org/10.1093/schbul/18.3.387

[40] Miller, P., Lawrie, S.M., Hodges, A., Clafferty, R., Cosway, R. and Johnstone, E.C. (2001) Genetic Liability, Illicit Drug Use, Life Stress and Psychotic Symptoms: Preliminary Findings from the Edinburgh Study of People at High Risk for Schizophrenia. Social Psychiatry and Psychiatric Epidemiology, 36, 338-342. http://dx.doi.org/10.1007/s001270170038

[41] Dawson, M.E., Schell, A.M., Rissling, A., Ventura, J., Subotnik, K.L. and Nuechterlein, K.H. (2010) Psychophysiological Prodromal Signs of Schizophrenic Relapse: A Pilot Study. Schizophrenia Research, 123, 64-67. http://dx.doi.org/10.1016/j.schres.2010.07.029

[42] Falkai, P., Schneider-Axmann, T. and Honer, W.G. (2000) Entorhinal Cortex Pre-Alpha Cell Clusters in Schizophrenia: Quantitative Evidence of a Developmental Abnormality. Biological Psychiatry, 47, 937-943.

[43] Jakob, H. and Beckmann, H. (1994) Circumscribed Malformation and Nerve Cell Alterations in the Entorhinal Cortex of Schizophrenics. Pathogenetic and Clinical Aspects. Journal of Neural Transmission/General Section JNT, 98, 83106. http://dx.doi.org/10.1007/BF01277013

[44] Kovalenko, S., Bergmann, A., Schneider-Axmann, T., Ovary, I., Majtenyi, K., Havas, L., Honer, W.G., Bogerts, B. and Falkai, P. (2003) Regio Entorhinalis in Schizophrenia: More Evidence for Migrational Disturbances and Suggestions for a New Biological Hypothesis. Pharmacopsychiatry, 36, 158-161. http://dx.doi.org/10.1055/s-2003-45124

[45] Parlapani, E., Schmitt, A., Erdmann, A., Bernstein, H.G., Breunig, B., Gruber, O., Petroianu, G., von Wilmsdorff, M., Schneider-Axmann, T., Honer, W. and Falkai, P. (2009) Association between Myelin Basic Protein Expression and Left Entorhinal Cortex Pre-Alpha Cell Layer Disorganization in Schizophrenia. Brain Research, 1301, 126-134. http://dx.doi.org/10.1016/j.brainres.2009.09.007

[46] Fung, S.J., Webster, M.J., Sivagnanasundaram, S., Duncan, C., Elashoff, M. and Weickert, C.S. (2010) Expression of Interneuron Markers in the Dorsolateral Prefrontal Cortex of the Developing Human and Inschizophrenia. American Journal of Psychiatry, 167, 1479-1488. http://dx.doi.org/10.1176/appi.ajp.2010.09060784

[47] Mellios, N., Huang, H.S., Baker, S.P., Galdzicka, M., Ginns, E. and Akbarian, S. (2009) Molecular Determinants of Dysregulated GABAergic Gene Expression in the Prefrontal Cortex of Subjects with Schizophrenia. Biological Psychiatry, 65, 1006-1014. http://dx.doi.org/10.1016/j.biopsych.2008.11.019

[48] Morris, H.M., Hashimoto, T. and Lewis, D.A. (2008) Alterations in Somatostatin mRNA Expression in the Dorsolateral Prefrontal Cortex of Subjects with Schizophreniaor Schizoaffective Disorder. Cerebral Cortex, 18, 1575-1587. 
http://dx.doi.org/10.1093/cercor/bhm186

[49] Reynolds, G.P. and Beasley, C.L. (2001) GABAergic Neuronal Subtypes in the Human Frontal Cortex-Development and Deficits in Schizophrenia. Journal of Chemical Neuroanatomy, 22, 95-100. http://dx.doi.org/10.1016/S0891-0618(01)00113-2

[50] Catts, V.S., Fung, S.J., Long, L.E., Joshi, D., Vercammen, A., Allen, K.M., Fillman, S.G., Rothmond, D.A., Sinclair, D., Tiwari, Y., Tsai, S.Y., Weickert, T.W. and Shannon Weickert, C. (2013) Rethinking Schizophrenia in the Context of Normal Neurodevelopment. Frontiers in Cellular Neuroscience, 15, 1-27.

[51] Cass, D.K., Flores-Barrera, E., Thomases, D.R., Vital, W.F., Caballero, A. and Tseng, K.Y. (2014) CB1 Cannabinoid Receptor Stimulation during Adolescence Impairs the Maturation of GABA Function in the Adult Rat Prefrontal Cortex. Molecular Psychiatry, 19, 536-543. http://dx.doi.org/10.1038/mp.2014.14

[52] Caballero, A., Thomases, D.R., Flores-Barrera, E., Cass, D.K. and Tseng, K.Y. (2014) Emergence of GABAergicDependent Regulation of Input-Specific Plasticity in the Adult Rat Prefrontal Cortex during Adolescence. Psychopharmacology, 231, 1789-1796. http://dx.doi.org/10.1007/s00213-013-3216-4

[53] Tseng, K.Y., Lewis, B.L., Hashimoto, T., Sesack, S.R., Kloc, M., Lewis, D.A. and O’Donnell, P. (2008) A Neonatal Ventral Hippocampal Lesion Causes Functional Deficits in Adult Prefrontal Cortical Interneurons. Journal of Neuroscience, 28, 12691-12699. http://dx.doi.org/10.1523/JNEUROSCI.4166-08.2008

[54] Hakak, Y., Walker, J.R., Li, C., Wong, W.H., Davis, K.L., Buxbaum, J.D., Haroutunian, V. and Fienberg, A.A. (2001) Genome-Wide Expression Analysis Reveals Dysregulation of Myelination-Related Genes in Chronic Schizophrenia. Proceedings of the National Academy of Sciences of the United States of America, 98, 4746-4751. http://dx.doi.org/10.1073/pnas.081071198

[55] Matthews, P.R., Eastwood, S.L. and Harrison, P.J. (2012) Reduced Myelin Basic Protein and Actin-Related Gene Expression in Visual Cortex in Schizophrenia. PLoS ONE, 7, Article ID: e38211.

[56] Kyriakopoulos, M., Vyas, N.S., Barker, G.J., Chitnis, X.A. and Frangou, S. (2008) A Diffusion Tensor Imaging Study of White Matter in Early-Onset Schizophrenia. Biological Psychiatry, 63, 519-523. http://dx.doi.org/10.1016/j.biopsych.2007.05.021

[57] Honer, W.G., Falkai, P., Chen, C., Arango, V., Mann, J.J. and Dwork, A.J. (1999) Synaptic and Plasticity-Associated Proteins in Anterior Frontal Cortex in Severe Mental Illness. Neuroscience, 91, 1247-1255. http://dx.doi.org/10.1016/S0306-4522(98)00679-4

[58] Akbarian, S., Bunney Jr., W.E., Potkin, S.G., Wigal, S.B., Hagman, J.O., Sandman, C.A. and Jones, E.G. (1993) Altered Distribution of Nicotinamide-Adenine Dinucleotide Phosphate-Diaphorase Cells in Frontal Lobe of Schizophrenics Implies Disturbances of Cortical Development. JAMA Psychiatry, 50, 169-177. http://dx.doi.org/10.1001/archpsyc.1993.01820150007001

[59] Weinberger, D.R., Torrey, E.F., Neophytides, A.N. and Wyatt, R.J. (1979) Lateral Cerebral Ventricular Enlargement in Chronic Schizophrenia. JAMA Psychiatry, 36, 735-739. http://dx.doi.org/10.1001/archpsyc.1979.01780070013001

[60] Glahn, D.C., Laird, A.R., Ellison-Wright, I., Thelen, S.M., Robinson, J.L., Lancaster, J.L., Bullmore, E. and Fox, P.T. (2008) Meta-Analysis of Gray Matter Anomalies in Schizophrenia: Application of Anatomic Likelihood Estimation and Network Analysis. Biological Psychiatry, 64, 774-781.

[61] Olabi, B., Ellison-Wright, I., McIntosh, A.M., Wood, S.J., Bullmore, E. and Lawrie, S.M. (2011) Are There Progressive Brain Changes in Schizophrenia? A Meta-Analysis of Structural Magnetic Resonance Imaging Studies. Biological Psychiatry, 70, 88-96. http://dx.doi.org/10.1016/j.biopsych.2011.01.032

[62] Benes, F.M., McSparren, J., Bird, E.D., San Giovanni, J.P. and Vincent, S.L. (1991) Deficits in Small Interneurons in Prefrontal and Cingulate Cortices of Schizophrenic and Schizoaffective Patients. JAMA Psychiatry, 48, 996-1001. http://dx.doi.org/10.1001/archpsyc.1991.01810350036005

[63] Roberts, G.W., Colter, N., Lofthouse, R., Johnstone, E.C. and Crow, T.J. (1987) Is There Gliosis in Schizophrenia? Investigation of the Temporal Lobe. Biological Psychiatry, 22, 1459-1468. http://dx.doi.org/10.1016/0006-3223(87)90104-1

[64] Heckers, S., Heinsen, H., Geiger, B. and Beckmann, H. (1991) Hippocampal Neuron Number in Schizophrenia. A Stereological Study. JAMA Psychiatry, 48, 1002-1008. http://dx.doi.org/10.1001/archpsyc.1991.01810350042006

[65] Porton, B. and Wetsel, W.C. (2007) Reduction of Synapsin III in the Prefrontal Cortex of Individuals with Schizophrenia. Schizophrenia Research, 94, 366-370. http://dx.doi.org/10.1016/j.schres.2007.04.016

[66] Broadbelt, K. and Jones, L.B. (2008) Evidence of Altered Calmodulin Immunoreactivity in Areas 9 and 32 of Schizophrenic Prefrontal Cortex. Journal of Psychiatric Research, 42, 612-621. http://dx.doi.org/10.1016/j.jpsychires.2007.07.006

[67] Arnold, S.E. and Trojanowski, J.Q. (1996) Recent Advances in Defining the Neuropathology of Schizophrenia. Acta Neuropathologica, 92, 217-231. http://dx.doi.org/10.1007/s004010050512 
[68] Anticevic, A., Cole, M.W., Repovs, G., Savic, A., Driesen, N.R., Yang, G., Cho, Y.T., Murray, J.D., Glahn, D.C., Wang, X.J. and Krystal, J.H. (2013) Connectivity, Pharmacology, and Computation: Toward a Mechanistic Understanding of Neural System Dysfunction in Schizophrenia. Frontiers in Psychiatry, 4, 1-21. http://dx.doi.org/10.3389/fpsyt.2013.00169

[69] Hu, M.R., Li, J., Eyler, L., Guo, X.F., Wei, Q.L., Tang, J.S., Liu, F., He, Z., Li, L.H., Jin, H., Liu, Z., Wang, J., Liu, F., Chen, H.F. and Zhao, J.P. (2013) Decreased Left Middle Temporal Gyrus Volume in Antipsychotic Drug-Naive, First-Episode Schizophrenia Patients and Their Healthy Unaffected Siblings. Schizophrenia Research, 144, 37-42. http://dx.doi.org/10.1016/j.schres.2012.12.018

[70] Penzes, P., Buonanno, A., Passafaro, M., Sala, C. and Sweet, R.A. (2013) Developmental Vulnerability of Synapses and Circuits Associated with Neuropsychiatric Disorders. Journal of Neurochemistry, 126, 165-182. http://dx.doi.org/10.1111/jnc.12261

[71] Kohen, R., Dobra, A., Tracy, J.H. and Haugen, E. (2014) Transcriptome Profiling of Human Hippocampus Dentate Gyrus Granule Cells in Mental Illness. Translational Psychiatry, 4, Article ID: e366. http://dx.doi.org/10.1038/tp.2014.9

[72] Bracht, T., Horn, H., Strik, W., Federspiel, A., Razavi, N., Stegmayer, K., Wiest, R., Dierks, T., Müller, T.J. and Walther, S. (2014) White Matter Pathway Organization of the Reward System Is Related to Positive and Negative Symptoms in Schizophrenia. Schizophrenia Research, 153, 136-142. http://dx.doi.org/10.1016/j.schres.2014.01.015

[73] DeLisi, L.E., Dauphinais, I.D. and Gershon, E.S. (1988) Perinatal Complications and Reduced Size of Brain Limbic Structures in Familial Schizophrenia. Schizophrenia Bulletin, 14, 185-191. http://dx.doi.org/10.1093/schbul/14.2.185

[74] Suddath, R.L., Casanova, M.F., Goldberg, T.E., Daniel, D.G., Kelsoe Jr., J.R. and Weinberger, D.R. (1989) Temporal Lobe Pathology in Schizophrenia: A Quantitative Magnetic Resonance Imaging Study. American Journal of Psychiatry, 146, 464-472.

[75] Suddath, R.L., Christison, G.W., Torrey, E.F., Casanova, M.F. and Weinberger, D.R. (1990) Anatomical Abnormalities in the Brains of Monozygotic Twins Discordant for Schizophrenia. New England Journal of Medicine, 322, 789794. http://dx.doi.org/10.1056/NEJM199003223221201

[76] Steen, R.G., Mull, C., McClure, R., Hamer, R.M. and Lieberman, J.A. (2006) Brain Volume in First-Episode Schizophrenia: Systematic Review and Meta-Analysis of Magnetic Resonance Imaging Studies. British Journal of Psychiatry, 188, 510-588. http://dx.doi.org/10.1192/bjp.188.6.510

[77] Tregellas, J.R. (2014) Neuroimaging Biomarkers for Early Drug Development in Schizophrenia. Biological Psychiatry, in press. http://dx.doi.org/10.1016/j.biopsych.2013.08.025

[78] Malchow, B., Hasan, A., Fusar-Poli, P., Schmitt, A., Falkai, P. and Wobrock, T. (2013) Cannabis Abuse and Brain Morphology in Schizophrenia: A Review of the Available Evidence. European Archives of Psychiatry and Clinical Neuroscience, 263, 3-13. http://dx.doi.org/10.1007/s00406-012-0346-3

[79] Wolf, C., Mohr, H., Schneider-Axmann, T., Reif, A., Wobrock, T., Scherk, H., Kraft, S., Schmitt, A., Falkai, P. and Gruber, O. (2014) CACNA1C Genotype Explains Interindividual Differences in Amygdala Volume among Patients with Schizophrenia. European Archives of Psychiatry and Clinical Neuroscience, 264, 93-102. http://dx.doi.org/10.1007/s00406-013-0427-y

[80] Antonova, E., Sharma, T., Morris, R. and Kumari, V. (2004) The Relationship between Brain Structure and Neurocognition in Schizophrenia: A Selective Review. Schizophrenia Research, 70, 117-145. http://dx.doi.org/10.1016/j.schres.2003.12.002

[81] Brambilla, P., Perlini, C., Rajagopalan, P., Saharan, P., Rambaldelli, G., Bellani, M., Dusi, N., Cerini, R., Pozzi Mucelli, R., Tansella, M. and Thompson, P.M. (2013) Schizophrenia Severity, Social Functioning and Hippocampal Neuroanatomy: Three-Dimensional Mapping Study. British Journal of Psychiatry, 202, 50-55. http://dx.doi.org/10.1192/bjp.bp.111.105700

[82] Law, A.J., Weickert, C.S., Hyde, T.M., Kleinman, J.E., Harrison, P.J., Law, A.J., Weickert, C.S., Hyde, T.M., Kleinman, J.E. and Harrison, P.J. (2004) Reduced Spinophilin but Not Microtubule-Associated Protein 2 Expression in the Hippocampal Formation in Schizophrenia and Mood Disorders: Molecular Evidence for a Pathology of Dendritic Spines. American Journal of Psychiatry, 161, 1848-1855. http://dx.doi.org/10.1176/appi.ajp.161.10.1848

[83] Kolomeets, N.S., Orlovskaya, D.D., Rachmanova, V.I. and Uranova, N.A. (2005) Ultrastructural Alterations in Hippocampal Mossy Fiber Synapses in Schizophrenia: A Postmortem Morphometric Study. Synapse, 57, 47-55. http://dx.doi.org/10.1002/syn.20153

[84] Kolomeets, N.S., Orlovskaya, D.D. and Uranova, N.A. (2007) Decreased Numerical Density of CA3 Hippocampal Mossy Fiber Synapses in Schizophrenia. Synapse, 61, 615-621. http://dx.doi.org/10.1002/syn.20405

[85] Medoff, D.R., Holcomb, H.H., Lahti, A.C. and Tamminga, C.A. (2001) Probing the Human Hippocampus Using rCBF: Contrasts in Schizophrenia. Hippocampus, 11, 543-550. http://dx.doi.org/10.1002/hipo.1070 
[86] Malaspina, D., Harkavy-Friedman, J., Corcoran, C., Mujica-Parodi, L., Printz, D., Gorman, J.M. and Van Heertum, R. (2004) Resting Neural Activity Distinguishes Subgroups of Schizophrenia Patients. Biological Psychiatry, 56, 931-937. http://dx.doi.org/10.1016/j.biopsych.2004.09.013

[87] Schobel, S.A., Lewandowski, N.M., Corcoran, C.M., Moore, H., Brown, T., Malaspina, D. and Small, S.A. (2009) Differential Targeting of the CA1 Subfield of the Hippocampal Formation by Schizophrenia and Related Psychotic Disorders. JAMA Psychiatry, 66, 938-946. http://dx.doi.org/10.1001/archgenpsychiatry.2009.115

[88] Varea, E., Castillo-Gómez, E., Gómez-Climent, M.A., Blasco-Ibáñez, J.M., Crespo, C., Martínez-Guijarro, F.J. and Nàcher, J. (2007) PSA-NCAM Expression in the Human Prefrontal Cortex. Journal of Chemical Neuroanatomy, 33, 202-209. http://dx.doi.org/10.1016/j.jchemneu.2007.03.006

[89] Barbeau, D., Liang, J.J., Robitaille, Y., Quirion, R. and Srivastava, L.K. (1995) Decreased Expression of the Embryonic Form of the Neural Cell Adhesion Molecule in Schizophrenic Brains. Proceedings of the National Academy of Sciences of the United States of America, 92, 2785-2789. http://dx.doi.org/10.1073/pnas.92.7.2785

[90] Ní Dhúill, C.M., Fox, G.B., Pittock, S.J., O’Connell, A.W., Murphy, K.J. and Regan, C.M. (1999) Polysialylated Neural Cell Adhesion Molecule Expression in the Dentate Gyrus of the Human Hippocampal Formation from Infancy to Old Age. Journal of Neuroscience Research, 55, 99-106. http://dx.doi.org/10.1002/(SICI)1097-4547(19990101)55:1<99::AID-JNR11>3.0.CO;2-S

[91] Gilabert-Juan, J., Varea, E., Guirado, R., Blasco-Ibáñez, J.M., Crespo, C. and Nácher, J. (2012) Alterations in the Expression of PSA-NCAM and Synaptic Proteins in the Dorsolateral Prefrontal Cortex of Psychiatric Disorder Patients. Neuroscience Letters, 530, 97-102. http://dx.doi.org/10.1016/j.neulet.2012.09.032

[92] Benes, F.M. and Berretta, S. (2001) GABAergic Interneurons: Implications for Understanding Schizophrenia and Bipolar Disorder. Neuropsychopharmacology, 25, 1-27. http://dx.doi.org/10.1016/S0893-133X(01)00225-1

[93] Guidotti, A., Auta, J., Davis, J.M., Dong, E., Grayson, D.R., Veldic, M., Zhang, X. and Costa, E. (2005) GABAergic Dysfunction in Schizophrenia: New Treatment Strategies on the Horizon. Psychopharmacology, 180, 191-205. http://dx.doi.org/10.1007/s00213-005-2212-8

[94] Lewis, D.A., Hashimoto, T. and Volk, D.W. (2005) Cortical Inhibitory Neurons and Schizophrenia. Nature Reviews Neuroscience, 6, 312-324. http://dx.doi.org/10.1038/nrn1648

[95] Rotaru, D.C., Yoshino, H., Lewis, D.A., Ermentrout, G.B. and Gonzalez-Burgos, G. (2011) Glutamate Receptor Subtypes Mediating Synaptic Activation of Prefrontal Cortex Neurons: Relevance for Schizophrenia. Journal of Neuroscience, 31, 142-156. http://dx.doi.org/10.1523/JNEUROSCI.1970-10.2011

[96] Nakazawa, K., Zsiros, V., Jiang, Z., Nakao, K., Kolata, S., Zhang, S.Q. and Belforte, J.E. (2012) GABAergic Interneuron Origin of Schizophrenia Pathophysiology. Neuropharmacology, 62, 1574-1583. http://dx.doi.org/10.1016/j.neuropharm.2011.01.022

[97] Jakob, H. and Beckmann, H. (1986) Prenatal Developmental Disturbances in the Limbic Allocortex in Schizophrenics. Journal of Neural Transmission, 65, 303-326. http://dx.doi.org/10.1007/BF01249090

[98] Rosoklija, G., Toomayan, G., Ellis, S.P., Keilp, J., Mann, J.J., Latov, N., Hays, A.P. and Dwork, A.J. (2000) Structural Abnormalities of Subicular Dendrites in Subjects with Schizophrenia and Mood Disorders: Preliminary Findings. JAMA Psychiatry, 57, 349-356. http://dx.doi.org/10.1001/archpsyc.57.4.349

[99] Masliah, E. and Diez-Tejedor, E. (2012) The Pharmacology of Neurotrophic Treatment with Cerebrolysin: Brain Protection and Repair to Counteract Pathologies of Acute and Chronic Neurological Disorders. Drugs of Today, 48, 3-24.

[100] Sharma, H.S., Muresanu, D.F., Patnaik, R., Stan, A.D., Vacaras, V., Perju-Dumbrav, L., Alexandru, B., Buzoianu, A., Opincariu, I., Menon, P.K. and Sharma, A. (2011) Superior Neuroprotective Effects of Cerebrolysin in Heat Stroke Following Chronic Intoxication of $\mathrm{Cu}$ or Ag Engineered Nanoparticles. A Comparative Study with Other Neuroprotective Agents Using Biochemical and Morphological Approaches in the Rat. Journal of Nanoscience and Nanotechnology, 11, 7549-7569. http://dx.doi.org/10.1166/jnn.2011.5114

[101] Ubhi, K., Rockenstein, E., Vazquez-Roque, R., Mante, M., Inglis, C., Patrick, C., Adame, A., Fahnestock, M., Doppler, E., Novak, P., Moessler, H. and Masliah, E. (2013) Cerebrolysin Modulates Pronerve Growth Factor/Nerve Growth Factor Ratio and Ameliorates the Cholinergic Deficit in a Transgenic Model of Alzheimer's Disease. Journal of Neuroscience Research, 91, 167-177. http://dx.doi.org/10.1002/jnr.23142

[102] Menon, P.K., Mures anu, D.F., Sharma, A., Mössler, H. and Sharma, H.S. (2012) Cerebrolysin, a Mixture of Neurotrophic Factors Induces Marked Neuroprotection in Spinal Cord Injury Following Intoxication of Engineered Nanoparticles from Metals. CNS \& Neurological Disorders-Drug Targets, 11, 40-49. http://dx.doi.org/10.2174/187152712799960781

[103] Panteleeva, G.P., Bondar', V.V., Krasnikova, N.I. and Raiushkin, V.A. (1999) Cerebrolysin and Magnesium-B6 in the Treatment of Side Effects of Psychotropic Drugs. Zhurnal Nevrologii i Psikhiatrii Imeni S.S. Korsakova, 99, 37-41.

[104] Krasnoperova, M.G., Bashina, V.M., Skvortsov, I.A. and Simashkova, N.V. (2003) The Effect of Cerebrolysin on 
Cognitive Functions in Childhood Autism and in Asperger Syndrome. Zhurnal Nevrologii i Psikhiatrii Imeni S.S. Korsakova, 103, 15-18.

[105] Radzivil, M.G. and Bashina, V.M. (2006) An Effect of Long-Term Cerebrolysin Therapy in Combination with Neuroleptics on Behavioral and Cognitive Disturbances in Endogenous Childhood Autism. Zhurnal Nevrologii i Psikhiatrii Imeni S.S. Korsakova, 106, 21-25.

[106] Xiao, S., Xue, H., Li, G., Yuan, C., Li, X., Chen, C., Wu, H.Z., Mitchell, P. and Zhang, M. (2012) Therapeutic Effects of Cerebrolysin Added to Risperidone in Patients with Schizophrenia Dominated by Negative Symptoms. Australian and New Zealand Journal of Psychiatry, 46, 153-160. http://dx.doi.org/10.1177/0004867411433213

[107] Lipska, B.K., Jaskiw, G.E. and Weinberger, D.R. (1993) Postpubertal Emergence of Hyperresponsiveness to Stress and to Amphetamine after Neonatal Excitotoxic Hippocampal Damage: A Potential Animal Model of Schizophrenia. Neuropsychopharmacology, 9, 67-75.http://dx.doi.org/10.1038/npp.1993.44

[108] Flores, G., Barbeau, D., Quirion, R. and Srivastava, L.K. (1996) Decreased Binding of Dopamine D3 Receptors in Limbic Subregions after Neonatal Bilateral Lesion of Rat Hippocampus. Journal of Neuroscience, 16, 2020-2026.

[109] Lipska, B.K. and Weinberger, D.R. (2000) To Model a Psychiatric Disorder in Animals: Schizophrenia as a Reality Test. Neuropsychopharmacology, 23, 223-239. http://dx.doi.org/10.1016/S0893-133X(00)00137-8

[110] Marcotte, E.R., Pearson, D.M. and Srivastava, L.K. (2001) Animal Models of Schizophrenia: A Critical Review. Journal of Psychiatry \& Neuroscience, 26, 395-410.

[111] Tseng, K.Y., Chambers, R.A. and Lipska, B.K. (2009) The Neonatal Ventral Hippocampal Lesion as a Heuristic Neurodevelopmental Model of Schizophrenia. Behavioural Brain Research, 204, 295-305. http://dx.doi.org/10.1016/j.bbr.2008.11.039

[112] Sams-Dodd, F., Lipska, B.K. and Weinberger, D.R. (1997) Neonatal Lesions of the Rat Ventral Hippocampus Result in Hyperlocomotion and Deficits in Social Behaviour in Adulthood. Psychopharmacology, 132, 303-310. http://dx.doi.org/10.1007/s002130050349

[113] Flores, G., Silva-Gómez, A.B., Ibáñez, O., Quirion, R. and Srivastava, L.K. (2005) Comparative Behavioral Changes in Postpubertal Rats after Neonatal Excitotoxic Lesions of the Ventral Hippocampus and the Prefrontal Cortex. Synapse, 56, 147-153. http://dx.doi.org/10.1002/syn.20140

[114] Le Pen, G. and Moreau, J.L. (2002) Disruption of Prepulse Inhibition of Startle Reflex in a Neurodevelopmental Model of Schizophrenia: Reversal by Clozapine, Olanzapine and Risperidone but Not by Haloperidol. Neuropsychopharmacology, 27, 1-11. http://dx.doi.org/10.1016/S0893-133X(01)00383-9

[115] Le Pen, G., Kew, J., Alberati, D., Borroni, E., Heitz, M.P. and Moreau, J.L. (2003) Prepulse Inhibition Deficits of the Startle Reflex in Neonatal Ventral Hippocampal-Lesioned Rats: Reversal by Glycine and a Glycine Transporter Inhibitor. Biological Psychiatry, 54, 1162-1670. http://dx.doi.org/10.1016/S0006-3223(03)00374-3

[116] Chambers, R.A., Moore, J., McEvoy, J.P. and Levin, E.D. (1996) Cognitive Effects of Neonatal Hippocampal Lesions in a Rat Model of Schizophrenia. Neuropsychopharmacology, 15, 587-594. http://dx.doi.org/10.1016/S0893-133X(96)00132-7

[117] Silva-Gómez, A.B., Bermudez, M., Quirion, R., Srivastava, L.K., Picazo, O. and Flores, G. (2003) Comparative Behavioral Changes between Male and Female Postpubertal Rats Following Neonatal Excitotoxic Lesions of the Ventral Hippocampus. Brain Research, 973, 285-292. http://dx.doi.org/10.1016/S0006-8993(03)02537-X

[118] Lipska, B.K., Khaing, Z.Z., Weickert, C.S. and Weinberger, D.R. (2001) BDNF mRNA Expression in Rat Hippocampus and Prefrontal Cortex: Effects of Neonatal Ventral Hippocampal Damage and Antipsychotic Drugs. European Journal of Neuroscience, 14, 135-144. http://dx.doi.org/10.1046/j.1460-9568.2001.01633.x

[119] Molteni, R., Lipska, B.K., Weinberger, D.R., Racagni, G. and Riva, M.A. (2001) Developmental and Stress-Related Changes of Neurotrophic Factor Gene Expression in an Animal Model of Schizophrenia. Molecular Psychiatry, 6, 285-292. http://dx.doi.org/10.1038/sj.mp.4000865

[120] Bhardwaj, S.K., Beaudry, G., Quirion, R., Levesque, D. and Srivastava, L.K. (2003) Neonatal Ventral Hippocampus Lesion Leads to Reductions in Nerve Growth Factor Inducible-B mRNA in the Prefrontal Cortex and Increased Amphetamine Response in the Nucleus Accumbens and Dorsal Striatum. Neuroscience, 122, 669-676. http://dx.doi.org/10.1016/j.neuroscience.2003.08.016

[121] Benes, F.M. (2010) Amygdalocortical Circuitry in Schizophrenia: From Circuits to Molecules. Neuropsychopharmacology, 35, 239-257. http://dx.doi.org/10.1038/npp.2009.116

[122] Martinotti, G., Di Iorio, G., Marini, S., Ricci, V., De Berardis, D. and Di Giannantonio, M. (2012) Nerve Growth Factor and Brain-Derived Neurotrophic Factor Concentrations in Schizophrenia: A Review. Journal of Biological Regulators and Homeostatic Agents, 26, 347-356.

[123] Ikegame, T., Bundo, M., Sunaga, F., Asai, T., Nishimura, F., Yoshikawa, A., Kawamura, Y., Hibino, H., Tochigi, M., Kakiuchi, C., Sasaki, T., Kato, T., Kasai, K. and Iwamoto, K. (2013) DNA Methylation Analysis of BDNF Gene Pro- 
moters in Peripheral Blood Cells of Schizophrenia Patients. Neuroscience Research, 77, 208-214. http://dx.doi.org/10.1016/j.neures.2013.08.004

[124] Lee, B.H. and Kim, Y.K. (2009) Increased Plasma Brain-Derived Neurotropic Factor, Not Nerve Growth Factor-Beta, in Schizophrenia Patients with Better Response to Risperidone Treatment. Neuropsychobiology, 59, 51-58. http://dx.doi.org/10.1159/000205518

[125] Zhang, X.Y., Liang, J., Chen, D.C., Xiu, M.H., Yang, F.D., Kosten, T.A. and Kosten, T.R. (2012) Low BDNF Is Associated with Cognitive Impairment in Chronic Patients with Schizophrenia. Psychopharmacology, 222, 277-284. http://dx.doi.org/10.1007/s00213-012-2643-y

[126] Ciobica, A., Padurariu, M., Dobrin, I., Stefanescu, C. and Dobrin, R. (2011) Oxidative Stress in Schizophrenia-Focusing on the Main Markers. Psychiatria Danubina, 23, 237-245.

[127] Smith, M.A. (2006) Oxidative Stress and Iron Imbalance in Alzheimer Disease: How Rust Became the Fuss! Journal of Alzheimer's Disease, 9, 305-308.

[128] Sultana, R., Piroddi, M., Galli, F. and Butterfield, D.A. (2008) Protein Levels and Activity of Some Antioxidant Enzymes in Hippocampus of Subjects with Amnestic Mild Cognitive Impairment. Neurochemical Research, 33, 25402546. http://dx.doi.org/10.1007/s11064-008-9593-0

[129] Hritcu, L., Ciobica, A., Stefan, M., Mihasan, M., Palamiuc, L. and Nabeshima, T. (2011) Spatial Memory Deficits and Oxidative Stress Damage Following Exposure to Lipopolysaccharide in a Rodent Model of Parkinson's Disease. Neuroscience Research, 71, 35-43. http://dx.doi.org/10.1016/j.neures.2011.05.016

[130] Flatow, J., Buckley, P. and Miller, B.J. (2013) Meta-Analysis of Oxidative Stress in Schizophrenia. Biological Psychiatry, 74, 400-409. http://dx.doi.org/10.1016/j.biopsych.2013.03.018

[131] Mahadik, S.P., Evans, D. and Lal, H. (2001) Oxidative Stress and Role of Antioxidant and $\omega$-3 Essential Fatty Acid Supplementation in Schizophrenia. Progress in Neuro-Psychopharmacology and Biological Psychiatry, 25, 463-493. http://dx.doi.org/10.1016/S0278-5846(00)00181-0

[132] Yao, J.K. and Keshavan, M.S. (2011) Antioxidants, Redox Signaling, and Pathophysiology in Schizophrenia: An Integrative View. Antioxidants \& Redox Signaling, 15, 2011-2035. http://dx.doi.org/10.1089/ars.2010.3603

[133] González, M.E., Francis, L. and Castellano, O. (1998) Antioxidant Systemic Effect of Short-Term Cerebrolysin ${ }^{\circledR}$ Administration. Journal of Neural Transmission, 53, 333-341. http://dx.doi.org/10.1007/978-3-7091-6467-9_29

[134] Patterson, P.H. (2011) Maternal Infection and Immune Involvement in Autism. Trends in Molecular Medicine, 17, 389-394. http://dx.doi.org/10.1016/j.molmed.2011.03.001

[135] Aguirre, A., Maturana, C.J., Harcha, P.A. and Sáez, J.C. (2013) Possible Involvement of TLRs and Hemichannels in Stress-Induced CNS Dysfunction via Mastocytes, and Glia Activation. Mediators of Inflammation, 2013, 1-17, Article ID: 893521.

[136] Atzori, M., Garcia-Oscos, F. and Mendez, J.A. (2012) Role of IL-6 in the Etiology of Hyperexcitable Neuropsychiatric Conditions: Experimental Evidence and Therapeutic Implications. Future Medicinal Chemistry, 4, 2177-2192. http://dx.doi.org/10.4155/fmc.12.156

[137] Suvisaari, J. and Mantere, O. (2013) Inflammation Theories in Psychotic Disorders: A Critical Review. Infectious Disorders-Drug Targets, 13, 59-70. http://dx.doi.org/10.2174/18715265112129990032

[138] Belokrylov, G.A. and Malchanova, I.V. (1992) Levamin and Cerebrolysin as Immunostimulants. Biulleten' Eksperimental'noù Biologii i Meditsiny, 113, 165-166.

[139] Sotnikova, N.Y., Gromova, O.A., Novikova, E.A. and Burtsev, E.M. (2000) Immunoactive Properties of Cerebrolysin. Russian Journal of Immunology, 5, 63-70.

[140] Garmanchuk, L.V., Perepelitsyna, E.M., Sidorenko, M.V., Makarenko, A.N. and Kul'chikov, A.E. (2009) Cytoprotective Effect of Neuropeptides on Immunocompetent Cells (in Vitro Study). Eksperimental'naia i Klinicheskaia Farmakologiia, 72, 28-32.

[141] West, A.E., Pruunsild, P. and Timmusk, T. (2014) Neurotrophins: Transcription and Translation. Handbook of Experimental Pharmacology, 220, 67-100. http://dx.doi.org/10.1007/978-3-642-45106-5_4 


\section{Abbreviations}

BDNF: Brain-Derived Neurotrophic Factor

BLA: Basolateral Amígdala

Cbl: Cerebrolysin

DA: Dopamine

EEG: Electroencephalography

Hc: Hippocampus

MRI: Magnetic Resonance Imaging

MBP: Myelin Basic Protein

NVHL: Neonatal Ventral Hippocampus Lesion

NAcc: Nucleus Accumbens

NGF: Neural Grow Factor

PD: Postnatal Day

PFC: Prefrontal Cortex

PSA-NCAM: Polisyalic Acid Neural Cell Adhesion Molecule

VTA: Ventral Tegmental Area 